\title{
THE EFFECT OF SMILE THERAPY AND EDUCATION IN PREGNANCY ON DECREASING LEVELS OF ANXIETY IN PRIM GRAVID
}

\author{
Sriyatin $^{1}$ \\ Prodi Keperawatan Cirebon Poltekkes Kemenkes Tasikmalaya \\ Corresponding email:atinsriyatin@yahoo.co.id
}

\begin{abstract}
Anxiety in pregnant women is due to pregnancy physical changes, preparing labor, and caring for children after childbirth. One intervention to overcome anxiety is smile therapy. Smiling is one of the easiest ways to reduce stress and make friendships. Smiling is not only an important nonverbal indicator of happiness but also as a medicine to deal with life's stress. This study aimed to determine the effect of smile therapy on reducing anxiety levels in Prim gravid women aged 4-8 months in the PHC in Cirebon City. This research was a quantitative study using a quasi-experimental design with a nonrandomized Pretest-Posttest Control Group Design. The number of samples in the study was 44 pregnant women. Data were analyzed by paired sample test with a significance level of $5 \%(0.05)$. The results showed a value of $p=0.009$, there was a difference in anxiety level scores between the intervention group and the control group after smile therapy intervention. The intervention of effective therapy to reduce the anxiety of prim gravid women during pregnancy, there is a needs further application of this therapy to other maternal phases such as labor or post-partum
\end{abstract}

Keywords: Anxiety, Pregnancy Education, Prim gravid, Smile Therapy

\section{INTRODUCTION}

Pregnancy is a physiological process in women related to the reproductive phase. Pregnancy is an exciting phase for a woman, however, for some women, it might be a stressful and challenging event, especially in the first pregnancy. Women face physical, physiological, and social changes that need adaptation. Psychological and emotional changes are related to biological changes experienced by women during pregnancy. Many conflicts arise such as the preparation of new roles as mothers, women's needs for careers in workplaces, and duties as a wife. Pregnancy causes changes including physical and psychological. Changes in women's psychological create anxiety and mood swings that may be caused women stress (Sibagariang, et al, 2010).

The psychological development during pregnancy varies according to the stage of pregnancy. In the second trimester, women begin to recognize fetal movements, realizing that the fetus is an individual, has his own needs, and temporarily lives in his body (Prawirodharjo, 2009). One of the psychological changes is an emotional response. Pregnant women experience emotional instability such as mood swings, jealousy, sensitivity, tend to be lazy, ask for more attention, feeling uncomfortable, anxious, depressed, and stressed. (Kencana, 2011). A fast mood change and increased sensitivity to others is a condition that sometimes overwhelms women themselves and those around them. Increased irritability, crying, anger, pleasure, and happiness fluctuating due to easy problems or no problems at all. (Bobak et al., 2005).

Anxiety is a response to the process of self-adjustment to changes in physiological and psychological functions. Pregnant women's anxieties are unpleasant emotions in the form of worry, 
fear, discomfort, feelings of confusion, and anxiety characterized by physical, behavioral and cognitive symptoms experienced by a woman when she conceives a fetus in her womb both in the first trimester, second, or third. The anxiety that occurs in pregnant women is related to anxiety about various physical changes, anxiety facing labor, and anxiety in caring for children. Women's anxiety and depression often occur during pregnancy and after childbirth (Heron et al, 2004). Women's wellbeing during pregnancy is very important for optimal fetal growth and development (Alder et al, 2007). Stress during pregnancy affects fetal growth including inhibiting growth or triggering premature birth, and low birth weight (Lobel et al, 2008). Some studies show the relationship between stress and anxiety in women with an increase in arterial blood pressure and a decrease in blood flow in the uterus will affect the function of the placenta. In addition, the fetus shows physiological reactivity when women are exposed to stressors.

Increasing stress levels, anxiety, and feelings of depression in pregnancy change physiological parameters, namely increased activity of regulation of hypothalamic pituitary adrenal (HPA) axis. HPA is one of the main stress systems in the human body that regulates the release of glucocorticoids, cortisol. The second important regulator of human stress reactivity is the sympathetic-adrenal medullary (SAM) system which releases the catecholamine norepinephrine (NE) and epinephrine (E). During pregnancy, catecholamine levels increase in women with work stress. Female and fetal cortisol levels are related to fetal brain growth and development (Ganong, 2001).

Smiling is one of the easiest ways to reduce stress. Less facial muscles are needed to make someone smile than sullen. Some experts say it takes 43 muscles to frown and 17 muscles to smile. Others say it takes 62 muscles to frown and 26 muscles to smile. "Smiling is an important nonverbal indicator of happiness and one way to deal with life's stress" (Tara Kraft, 2017). Smiles activate the release of neuropeptides - namely intermediate small molecules between nerve cells to communicate to relieve stress. Neuropeptides connect emotions and feelings so that the organs of the body will know if there is a change in moods, such as sadness, anger, or excitement. When smiling dopamine, serotonin, and endorphins - called happy hormones - are released. This release causes the heart rate to decrease, the body relaxes and lowers blood pressure. Endorphins are also known as pain relievers and there are no side effects.

The results of the study by Neny Dwi Pebriasanty (2014) stated that there was a significant difference in the decrease in nausea and vomiting with smile therapy. The results of Ni Made Sumartyawati's research state that there is an effect of smile therapy on changes in blood pressure in the elderly. Interviews with several women who examined Pregnancy at the Puskesmas PONED Cirebon City said they were worried about the pregnancy they had experienced. Anxiety includes anxiety about one's own condition and the condition of his fetus, in the PHC, Cirebon City, no one has conducted research on smile therapy for pregnant women. Researchers are interested in conducting research on the effects of smile therapy and pregnancy education on reducing anxiety levels in pregnant women aged 4-8 months. 


\section{METHODS}

The research design was quasi-experimental with a nonrandomized pretest-posttest control group design approach. The study was conducted to determine whether there was a change in the group before and after treatment (Notoatmodjo, 2010). Anxiety in pregnant women was measured using an anxiety scale that includes physiological/physical, behavioral, and cognitive aspects (Nevid et al, 2003). The population in this study were primigravid aged 4-8 months, totaling 30 respondents, in the PHC in Cirebon City.

\section{RESULTS}

Univariate Analysis

The results of the univariate analysis are described in the table below:

1. Respondents by the Primary Health Care (PHC) background

Table 1 Distribution of the intervention group respondents by the PHC

\begin{tabular}{lccc} 
& & \multicolumn{2}{c}{ Distribution } \\
\cline { 2 - 3 } & PHC & $\mathrm{n}$ & $\%$ \\
\hline Pamitran & 2 & 6,7 \\
Cangkol & 8 & 26,7 \\
Gunungsari & 6 & 20 \\
Pegambiran & 7 & 23,3 \\
Sitopeng & & 7 & 23,3 \\
& Total & 30 & 100 \\
\hline
\end{tabular}

Table 1 presents the majority of respondents from the Cangkol health center as many as 8 people $(26.7 \%)$.

Table 2 Distribution of the control group respondents by the PHC

\begin{tabular}{lccc}
\hline & PHC & \multicolumn{2}{c}{ Distribution } \\
\cline { 3 - 4 } & & $\mathrm{n}$ & $\%$ \\
\hline Beber & 12 & 40 \\
Plered & 8 & 26,7 \\
Plumbon & & 10 & 33,3 \\
& Total & 30 & 100 \\
\hline
\end{tabular}


Sriyatin : The Effect of Smile Therapy and Education in Pregnancy

Table 2 describes that most of the respondents from the Beber Health Center were 12 people $(40 \%)$.

2. The characteristic of Respondents

Table 3. The characteristic of Respondents

\begin{tabular}{lcccc}
\hline \multirow{2}{*}{ Characteristic } & \multicolumn{5}{c}{ Smile Therapy } \\
\cline { 2 - 5 } & \multicolumn{3}{c}{ Yes } & \multicolumn{2}{c}{ No } \\
\cline { 2 - 5 } & $\mathrm{n}$ & $\%$ & $\mathrm{n}$ & $\%$ \\
\hline Occupations & 28 & 93,4 & 29 & 96,7 \\
Housewife & 1 & 3,3 & 0 & 0 \\
Government officer & 1 & 3,3 & 1 & 3,3 \\
Private sector & & & & \\
Education & 2 & 6,7 & 5 & 16,7 \\
Elementary School & 6 & 20 & 9 & 30 \\
Junior High School & 20 & 66,7 & 15 & 50 \\
Senior High School & 2 & 6,7 & 1 & 3,3 \\
University & 30 & 100 & 30 & 100 \\
$\quad$ Total & & & & \\
\end{tabular}

Table 3 can be explained that the majority of respondents from both the intervention and control groups worked as housewives, namely 28 people (93.4\%) and 29 people (96.7\%). Most of them attended the high school / high school which are 20 people $(66.7 \%)$ and 15 people $(50 \%)$ respectively.

3. Anxiety

Table 4 Anxiety levels before smile therapy and pregnancy education

\begin{tabular}{cccc} 
Variable & Mean & SD & Min - Mak \\
\hline The Intervention group & 23,40 & 9,75 & $9-46$ \\
The control group & 24,30 & 9.06 & $5-47$ \\
\hline
\end{tabular}

Table 4 informs that respondents in the intervention group had the lowest anxiety level of 9 and the highest of 46, an average of 23.4 with a standard deviation of 9.75 . While the respondents in the control group had the lowest anxiety level of 5 and the highest of 47 , an average of 24.30 with a standard deviation of 9.06 
Sriyatin : The Effect of Smile Therapy and Education in Pregnancy

Table 5 Anxiety levels after smile therapy and pregnancy education

\begin{tabular}{cccc} 
Variable & Mean & SD & Min - Mak \\
\hline The Intervention group & 18,70 & 9,14 & $4-38$ \\
The control group & 24,90 & 8,60 & $6-42$ \\
\hline
\end{tabular}

Table 5 describes that the intervention group respondents have the lowest anxiety level of 4 and the highest of 38 , an average of 18.70 with a standard deviation of 9.14. While respondents in the control group had the lowest anxiety level of 6 and the highest of 42, averaging 24.90 with a standard deviation of 8.60 .

Bivariate Analysis

1. Effects of Smile Therapy and Pregnancy Education on Anxiety

Table 6 Differences in the Anxiety Level between Intervention Groups and the control group

\begin{tabular}{cccccccc}
\hline Variable & Mean & SD & Min & Maks & t & df & P value \\
\hline $\begin{array}{c}\text { Before } \\
\text { intervention }\end{array}$ & $-0,833$ & 2,423 & $-5,684$ & 4,018 & $-0,344$ & 58 & 0,732 \\
$\begin{array}{c}\text { After } \\
\text { intervention }\end{array}$ & $-6,200$ & 2,291 & $-10,785$ & $-1,615$ & $-2,707$ & 58 & 0,009 \\
\hline
\end{tabular}

Table 6 explains that before smile therapy and pregnancy education, the lowest difference in anxiety level scores between the intervention groups and the control group was $-5,684$ and the biggest difference in anxiety level scores between intervention groups with controls was 4,018, the average difference in anxiety level scores between intervention groups with the control group was -0.833 and the standard deviation was 2.423 . The results of statistical analysis obtained a value of $p=0.723$, or Ho is not rejected, meaning that there is no difference in the level of anxiety scores between the intervention group and the control group.

Whereas after smile therapy and pregnancy education, the lowest difference in the anxiety level score between the intervention group and the control group was -10.785 and the biggest difference in the anxiety level score between the intervention and control groups was -1.614 , the average difference in anxiety level scores was $-6,200$ and the standard deviation is 2,291 . The results of the statistical analysis obtained a value of $\mathrm{p}=0.009$, or Ho was rejected, meaning that there was a difference in the level of anxiety scores between the intervention group and the control group. 
Sriyatin : The Effect of Smile Therapy and Education in Pregnancy

\section{DISCUSSION}

\section{The level of anxiety}

The results showed that respondents' anxiety levels before smile therapy and pregnancy education were 23.47 in the intervention group and 24.30 in the control group and this was in the category of moderate anxiety. This shows the similarity of anxiety levels between the intervention group and the control group. After smile therapy and pregnancy education in the intervention group, the level of anxiety dropped to 18.70 , but still in the category of moderate anxiety

\section{Effect of Smile Therapy and pregnancy education on decreasing anxiety level}

The results showed that there was an effect of smile therapy and pregnancy education on the decrease in anxiety in pregnant women. This is in accordance with the theory from Stuart \& Sundeen (2008) which states that one of the factors that arise from anxiety is the level of knowledge. Increasing women's knowledge about pregnancy through pregnancy education is expected to reduce the anxiety of pregnant women. In addition, the results of this study are in line with the theory which states that with a smile can stimulate the release of endorphins and serotonin which can affect the decrease in anxiety. Likewise with a study from Sheni Desinta (2013) which states that smile therapy can reduce anxiety and high blood pressure.

\section{CONCLUSION}

There is the influence of smile therapy and pregnancy education on decreasing anxiety levels in pregnant women. The socialization and application of smile therapy in health services, especially maternity nursing, will be beneficial for improving maternal welfare during the maternal period (pregnancy, maternity and post-partum).

\section{REFERENCES}

Ann, Isaacs. (2005) . Keperawatan Kesehatan Jiwa \& Psikiatrik. Jakarta : EGC.

Bobak. (2005) . Keperawatan Maternitas . Jakarta : EGC

Davidoff, L.L. (1991) . Psikologi Suatu Pengantar Diterjemahkan oleh Mari Juniarti, Jilid II. Jakarta : Erlangga

Gerald Corey. (2012). Theory and Practice of Counseling and Psychotherapy, Brooks/Cole

Gurung, R. A. R., Schetter, C. D., Collins, N., Rini, C., \& Hobel, C. J. (2005). Psychosocial Predictors Of Prenatal Anxiety. Journal of Social and Clinical Psychology, 24(4): 497-519.

Hawari, D.Hamayemen. (2006). Stres, Cemas dan Depresi . Jakarta : Balai Penerbit Fakultas Kedokteran Universitas Indonesia http://digilib.unimus.ac.id/files/disk1/136/jtptunimus-gdl-liyamuslim-6791-3-babii.pdf 
Sriyatin : The Effect of Smile Therapy and Education in Pregnancy

Http://waroengsehat.com/mengobati-keganasan-hipertensi-dengan-terapi-senyum-dan-zikir/ diakses 7

November 2017

Kompas.health.com diakses tanggal 20 November 2017

Lahey, Benjamin B. and Ciminero, Anthony R. (1980). Maladaptive behavior: An introduction to abnormal psychology. Scott, Foresman (Glenview, Ill.)

Lazarus \& Folkman's. (1984). Problem Based-Coping

Nevid, J.S., Rathus, S.A., \& Greene, B. (2003). Psikologi abnormal. Jakarta: Erlangga.

Notoatmojo S. (2005). Metodologi Penelitian Kesehatan. Jakarta : Rineka Cipta

Nursalam. (2011). Konsep dan Penerapan Metode Penelitian Ilmu Keperawatan, Pedoman Skripsi, Tesis dan Instrumen Penelitian Keperawatan, Edisi II. Jakarta : Salemba Medika.

Pieter HZ, Lubis NL. (2011). Pengantar Psikologi Untuk Kebidanan. Jakarta : Kencana.

Richard S. Lazarus, A. (2007). New Synthesis, Stress and Emotion. Springer Publishing Company.

Sarafino, E.P, (2006). Health Psychology : Biopsychosocial Interactions, Fifth Edition. USA : John Wiley \& Sons

Sevilla, Consuelo G. et. al (2007). Research Methods.

Sheila L Videbeck. (2008). Buku Ajar Keperawatan Jiwa, Edisi I, Jakarta : EGC.

Stuart GW, Sundeen SJ. (2008). Principle and Practice of Psychiatric Nursing, St Louis Missouri. Mosby Year Book Inc. 